\title{
PEMBANGUNAN EKONOMI ISLAMI \\ MENURUT FAHIM KHAN DAN UMER CHAPRA: SEBUAH KAJIAN KOMPARATIF
}

\author{
Wiwin Fitriyah \\ Universitas Islam Lamongan \\ e-mail: wiwinfitriyah@yahoo.com
}

\begin{abstract}
Every economic system in the world is the ultimate goal of creating a prosperous, just and equitable life. The effort to achieve this goal is economic development. The highest achievement in the Islamic economic system is the fulfillment of falāh, while falăh can be achieved by fulfilling the concept of maqāsid shariah, meaning say, preservation of beliefs, soul, spirit, heredity and property. Some theories about economic development strategies are often formulated by conventional economists framed by the ideology of capitalism and socialism. But the idea cannot be separated from the critical projector. In the ranks of contemporary Islamic economic thinkers, criticism of Western development strategies is accompanied by an alternative offer. The object of this research is the reflection of Fahim Khan and Umer Chapra on economic development. This research uses qualitative method, with comparative descriptive analysis technique. From the existing data, the author tries to describe the two objects of research and analyze it, then compare the results of two research objects. After knowing the location of equations and differences, the authors analyze the factors that underlie it. The results show that there are similarities with the problems faced by developing countries. This is the high rate of unemployment or overwork. Fahim Khan also proposes economic development strategies for surplus countries by opening up and animating entrepreneurship as well as institutional support based on a partnership with the system (profit and loss sharing). If the theory of Chapra has nothing to do with the strategy it proposes, it is only the result of the criticism of capitalist and socialist existence that has failed to overcome the problems facing the developing countries. Its strategy focuses on four important elements: moral filters, correct motivation, socio-economic restructuring and the role of the state. There are 5 characteristics that influence the factors that cause the differences and similarities between Fahim Khan's and Umer Chapra's theories on economic development: action, context, history, power, and ideology.
\end{abstract}

Keywords: Fahim Khan's Theory, Umer Chapra's Thoughts, Islamic Economic Development

\section{Pendahuluan}

Sejauh ini, tidak satu pun sistem ekonomi di dunia yang mampu memberi solusi bagi persoalan ekonomi manusia secara memuaskan. Hanyalah sistem ekonomi Islam yang memberi solusi yang indah bagi semua masalah ekonomi. ${ }^{1}$ Sistem ekonomi apapun di dunia ini tujuan akhirnya adalah terciptanya kehidupan yang sejahtera, adil, dan merata. Salah satu

\footnotetext{
${ }^{1}$ Muhammad Sharif Chaudry, Prinsip Dasar Sistem Ekonomi Islam, Terj. Suherman Rosyidi (Jakarta: Kencana, 2012), 353.
} 
upaya untuk mencapai tujuan itu adalah melalui pembangunan ekonomi. Pencapaian tertinggi dalam sistem ekonomi Islam adalah tercapainya falăh, sedangkan falăh dapat tercapai dengan pemenuhan konsep maqāṣid al-sharī ${ }^{\dagger} a h$, yaitu terpeliharanya keyakinan, jiwa, pikiran, keturunan dan harta.

Di sisi lain strategi pembangunan ekonomi belum banyak dikembangkan dalam khazanah pemikiran ekonomi Islam, padahal secara lazim negara-negara Islam sangat memerlukan strategi jitu dalam mengatasi keterpurukan ekonomi. Beberapa teori tentang strategi pembangunan banyak dirumuskan oleh para ekonom konvensional yang banyak dibingkai oleh faham kapitalisme maupun sosialisme. Namun gagasan tersebut tidak terlepas dari berbagai sorotan kritis.

Dalam jajaran para pemikir ekonomi Islam, kritik terhadap strategi pembangunan Barat disertai tawaran alternatif yang dilontarkan oleh Umer Chapra dan tidak kalah menarik juga seorang pemikir ekonomi Islam yang 13 tahun lebih muda dari beliau, yaitu Fahim Khan. Keduanya merupakan tokoh ekonom muslim era kontemporer yang sama-sama turut berkontribusi dalam mencetuskan gagasan tentang pembangunan ekonomi yang islami.

Tulisan ini mengungkap kejelasan pemikiran Fahim Khan dan Umer Chapra mengenai pembangunan ekonomi islami. Kemudian mencari perbandingan dari substansi pemikiran kedua tokoh tersebut, serta menganalisis faktor-faktor yang melatarbelakangi adanya perbedaan ataupun persamaan pemikiran tentang pembangunan ekonomi islami menurut Fahim Khan dan Umer Chapra.

\section{Pembahasan}

Istilah pembangunan ekonomi yang dimaksud dalam Islam adalah "the process of allaviating poverty and provision of ease, comfort and decency in life" (proses untuk mengurangi kemiskinan serta menciptakan ketentraman, kenyamanan dan tata susila dalam kehidupan). Dalam pengertian ini, maka pembangunan ekonomi menurut Islam bersifat multi dimensi yang mencakup aspek kuantitatif dan kualitatif. Tujuannya bukan semata-mata kesejahteraan material di dunia, tetapi juga kesejahteraan akhirat. ${ }^{2}$

Dalam perspektif Islam, pembangunan dilaksanakan berdasarkan lima pondasi filosofis, yaitu tauḥid ulühiyyah, tauhìid rubübiyyah, khiläfah, tazkiyyah al-nas, dan al-falāh. Kelima pondasi filosofis tersebut merupakan prinsip-prinsip yang telah melekat dalam Islam dan berasal dari dua sember utama Islam, yakni al-Quran dan Sunnah.

\section{Biografi Fahim Khan dan Umer Chapra}

Tokoh yang bernama lengkap Muhammad Fahim Khan, lahir di India pada tahun 1946. Fahim Khan termasuk jajaran ahli ekonomi Islam kontemporer yang memiliki kapabilitas yang handal secara akademis sekaligus memiliki pengalaman praktis dalam pengembangan ekonomi Islam. ${ }^{3}$

\footnotetext{
${ }^{2}$ M. Rizal Ismail "Pembangunan Ekonomi Menurut Islam”, dalamhttp://mrizalismail.blogspot.co. id/2012/01/pembangunan-ekonomi-menurut-islam.html, Diakes pada 15 Maret 2018.

${ }^{3}$ Ali Murtadho, "Formulasi Konsep Islam Tentang Pembangunan Ekonomi Padat Penduduk: Analisis Pemikiran Fahim Khan” (Laporan Penelitian Individual--LP2M UIN Walisongo Semarang, 2014), 58.
} 
Dengan gelar Masternya di bidang ekonomi politik, statistik dan Ph.D di bidang ekonomi, Fahim Khan memiliki 39 tahun pengalaman dalam bidang kebijakan dan perencanaan ekonomi, pengajaran dan pelatihan, pengembangan kapasitas kelembagaan dan penelitian, serta bidang konsultasi. Beliau memperoleh gelar B.A. dan M.A. dalam bidang statistik dari Universitas Punjab (Pakistan) pada tahun 1968, serta M.A. pada tahun 1977, dan Ph.D dalam ilmu ekonomi dari Universitas Boston (Amerika Serikat) pada tahun 1978. ${ }^{4}$

Beliau bergabung dengan Islamic Research and Trainning Institute (IRTI) sejak tahun 1988 dan menduduki berbagai posisi kepala divisi riset, kepala divisi pelatihan, serta kepala divisi pengembangan dan kerjasama ekonomi Islam. Fahim Khan juga pernah menjabat sebagai direktur IRTI selama setahun. Sebelum bergabung dengan IRTI, beliau menjabat Deputy Chief Kementrian Perencanaan (1969-1981), dan juga sebagai Profesor Ekonomi dan Direktur School of Economics di International Islamic University, Islamabad Pakistan pada tahun 1981-1988. ${ }^{5}$

Sedangkan M. Umer Chapra lahir pada tanggal 1 Februari 1933 di Bombay India. Beliau adalah salah satu ekonom kontemporer muslim yang paling terkenal pada zaman modern ini di Timur dan Barat. Ayahnya bernama Abdul Karim Chapra. Keluarganya tergolong tipe yang taat beragama, sehingga ia tumbuh menjadi sosok dengan karakter yang baik. Secara ekonomi, keluarganya termasuk berkecukupan sehingga memungkinkan ia mendapatkan pendidikan yang baik. Umer Chapra menikahi Khairunnisa Jamal Mundia tahun 1962 dan mempunyai empat anak, yaitu Maryam, Anas, Sumayyah dan Ayman. ${ }^{6}$

Masa kecilnya, beliau habiskan di tanah kelahirannya hingga berumur 15 tahun. Kemudian ia pindah ke Karachi untuk meneruskan pendidikannya di sana sampai meraih gelar Ph.D dari Universitas Minnesota. ${ }^{7}$

\section{Pemikiran Fahim Khan Tentang Pembangunan Ekonomi Islami}

Secara umum kualitas sumber daya manusia di negara-negara berkembang masih rendah, baik dari sisi pendidikan maupun skill manajemen kewirausahaannya. Memberikan peluang wirausaha kepada mereka bukan berarti menyediakan pabrik besar atau toko besar untuk dikelola. Memberikan peluang kewirausahaan berarti memberikan kesempatan kepada mereka untuk melakukan usaha yang dapat mereka kelola sendiri, misalnya membuka peluang atau memfasilitasi mereka yang memiliki ketrampilan dasar, baik sebagai tukang kayu, penjahit, tukang bangunan, pembuat makanan kecil dan sebagainya untuk mendirikan unit manufaktur kecil yang mempekerjakan beberapa orang saja yang mungkin berasal dari anggota keluarga mereka sendiri. Kesuksesan usaha bukan milik mereka yang berpendidikan tinggi saja, tidak jarang ada orang yang buta huruf dan tidak berpendidikan sukses menjalankan usaha kecil-usaha kecil dengan penghasilan yang tidak kalah dari gaji tetap

\footnotetext{
4 Markfield Institute Of Hinger Education, "Dr M Fahim Khan”, dalamhttps://www.mihe.ac.uk/ho norary-visiting-fellows/dr-m-fahim-khan, Diakses pada 31 Januari 2018.

5 Markfield Institute Of Hinger Education, "Dr M Fahim Khan", dalamhttps://www.mihe.ac.uk/ho norary-visiting-fellows/dr-m-fahim-khan, Diakses pada 31 Januari 2018.

${ }^{6}$ Wikipedia.org, "M. Umer Chapra", dalam https://id.m.wikipedia.org/wiki/M._Umer_Chapra, Diakses pada 31 Januari 2018.

${ }^{7}$ Ali Murtadho, "Strategi Pembangunan Ekonomi yang Islami Menurut Fahim Khan" dalam Jurnal Economica, Vol. 7, Edisi. 2, Oktober 2016, 2.
} 
pegawai atau karyawan. Bahkan dewasa ini banyak diwacanakan dalam beberapa literatur tentang pentingnya pengembangan industri skala kecil. ${ }^{8}$

Fahim Khan mengambil contoh kasus di Pakistan dan Indonesia sebagai negara dengan kondisi ekonomi berlimpah tenaga kerja. Di negara-negara ini orang menganggur bukan karena tidak mau bekerja, tetapi karena mereka tidak mendapatkan pekerjaan sesuai apa yang mereka bisa kerjakan. Dengan pendapatan perkapita yang masih rendah, tentu orang-orang ini memiliki keinginan kuat untuk meningkatkan taraf kehidupan yang lebih baik dengan bekerja. Ketika tidak ada penawaran pekerjaan, mereka tidak dapat menjalankan bisnis atau usaha mandiri karena tidak memiliki modal sendiri. Pada umumnya negara dengan surplus tenaga kerja, sebagian besar sumber daya manusianya tidak memiliki modal. Mereka membutuhkan pinjaman modal jika ingin melakukan usaha mandiri. ${ }^{9}$

Sehingga pemikiran pembangunan ekonomi menurut Fahim Khan difokuskan pada strategi pembangunan ekonomi perspektif Islam di negara dengan surplus tenaga kerja, karena permasalahan tersebut sebagian besar merupakan faktor penghambat pembangunan ekonomi suatu negara, khusunya negara-negara yang sedang berkembang seperti yang telah dicontohkan di atas. Pandangan Fahim Khan tentang strategi pembangunan ekonomi islami:

1. Pertumbuhan kewirausahaan di dalam perekonomian

Kerangka kelembagaan ekonomi Islam memiliki cerminan yang sangat jelas untuk menciptakan dan mendorong kegiatan kewirausahaan dalam kegiatan perekonomian. Unsur-unsur kerangka kelembagaan berikut ini menunjuk pada tujuan tersebut. ${ }^{10}$

Pertama, ajaran Islam tidak mengizinkan sumber daya (baik manusia maupun fisik) disimpan menganggur. Ada beberapa pengaturan kelembagaan (selain norma-norma moral) yang akan mengarahkan ke tujuan tersebut dalam perekonomian Islam. ${ }^{11}$

Kedua, ada pengaturan kelembagaan yang memaksa salah satu sumber daya yang langka dalam perekonomian, yakni modal finansial untuk aktivitas kewirausahaan dari pada disewakan untuk memperoleh sewa modal. Fahim Khan menegaskan bahwa modal keuangan dilarang keras untuk memperoleh sewa, yaitu bunga. Satu-satunya cara agar modal keuangan dapat menghasilkan pendapatan adalah dengan melibatkannya dalam aktivitas kewirausahaan di mana keuntungan yang akan diperoleh merupakan imbalan resiko kerugian produktif. Membiarkan modal finansial menganggur juga tidak disukai. Ada beban pungutan zakat atas sumber daya jika tidak digunakan dalam kegiatankegiatan produktif. ${ }^{12}$

Ketiga, dorongan bagi sumber daya keuangan untuk terlibat dalam kegiatan kewirausahaan akan menciptakan permintaan terhadap sumber daya komplementer untuk dipekerjakan pada basis wirausaha yang memakai modal finansial tersebut. Modal finansial tidak dapat menghasilkan apa-apa tanpa melibatkan sumber komplementer. Sumber daya komplementer yang terbaik adalah sumber daya manusia, terutama ketika sumber daya manusia ini sangat banyak sehingga modal finansial dapat menegosiasikan rasio bagi-hasil yang lebih baik. Dengan demikian, pengaturan institusional Islam seperti

\footnotetext{
${ }^{8}$ Ali Murtadho, "Strategi Pembangunan Ekonomi yang Islami, 3.

${ }^{9}$ Ibid., 4.

${ }^{10}$ Fahim Khan, Esai-Esai Ekonomi Islam, Terj. Suherman Rosyidi (Jakarta: Rajawali Pers, 2014), 231.

11 Ibid., 232.

12 Ibid.
} 
ini tidak hanya memaksa sumber daya finansial untuk menjadi sumber daya wirausaha, tetapi juga menciptakan permintaan sumber daya manusia. ${ }^{13}$

Keempat, pengaturan kelembagaan terkait jaminan sosial dan tidak adanya bunga pada modal finansial akan mendorong sumber daya manusia dalam perekonomian Islam untuk lebih mencari aktivitas kewirausahaan dari pada pekerjaan dengan upah tetap. Pada dasarnya aktivitas kewirausahaan menyediakan lebih banyak peluang pertumbuhan ekonomi dibandingkan dengan pekerjaan upah tetap. Orang akan termotivasi untuk memaksimalkan pendapatan hari ini dan masa mendatang. Orang akan lebih memilih kegiatan kewirausahaan dari pada pekerjaan berupah tetap ketika risiko wirausaha tidak lebih berat pendapatan yang diharapkan. ${ }^{14}$

Dalam ekonomi konvensional berbasis bunga, yang dipertaruhkan dalam sebuah aktivitas kewirausahaan jauh lebih berat dari pada pekerjaan berupah tetap. Risiko berwirausaha dalam ekonomi berbasis bunga meliputi seluruh upaya manusia diinvestasikan, seluruh modal keuangan yang diinvestasikan, serta bunga yang yang harus dibayarkan atas modal keuangan. Seorang wirausahawan yang melakukan usaha bukan dengan modal sendiri ketika mengalami kerugian menanggung beban yang amat berat. Dia harus mengembalikan modal pinjaman dengan seluruh bunganya. Dia juga menghadapi bahaya kelaparan untuk dirinya sendiri dan keluarganya. Melihat beratnya risiko tersebut, pekerjaan yang berupah tetap yang menjamin paling tidak kebutuhan dasar kehidupan (subsistensi) akan selalu lebih disukai.

Berbeda dengan sistem ekonomi Islam yang secara institusional menjamin kebutuhan hidup minimal dan melarang bunga, individu yang berwirausaha akan menghadapi risiko yang jauh lebih sedikit. Risiko akan dibagi antara pelaku wirausaha dan pemilik modal finansial. Risiko finansial bahkan ditanggung sepenuhnya oleh para pemilik modal finansial. Ketika terjadi kerugian, tidak ada kewajiban untuk mengembalikan modal karena pelaku usaha sudah mempertaruhkan sumber daya manusia yang dimilikinya.

Ketika terjadi kebangkrutan usaha, tidak ada ketakutan kelaparan karena masyarakat menjamin kebutuhan pokoknya. Dalam suasana yang demikian, sumber daya manusia akan lebih tertarik mencari kegiatan kewirausahaan dari pada pekerjaan dengan upah tetap (gaji). Mereka akan memiliki pekerjaan tetap hanya sebatas sampai mereka dapat menemukan modal finansial yang diperlukan untuk memulai kegiatan kewirausahaan.

Dari analisis Fahim Khan tersebut, ia menyimpulkan bahwa dalam kerangka kelembagaan dan kerangka etis ekonomi Islam, yang lebih ditawarkan adalah wirausaha, dari pada sewa tenaga kerja berupah tetap. Sistem ini menciptakan penawaran sekaligus permintaan wirausahawan dalam ekonomi. Semakin banyak wirausaha ditawarkan, semakin banyak upaya berbagi risiko produktif dan semakin banyak pula terjadinya percepatan pertumbuhan ekonomi.

2. Akumulasi modal

\footnotetext{
${ }^{13}$ Ibid.

${ }^{14}$ Fahim Khan, Esai-Esai Ekonomi Islam, 233.
} 
Fahim Khan membantah adanya anggapan bahwa akumulasi modal dalam ekonomi Islam lebih lambat dibandingkan dalam ekonomi berbasis bunga. Ia bahkan mengemukakan beberapa alasan untuk meyakinkan bahwa akumulasi modal akan lebih tinggi dalam ekonomi Islam. ${ }^{15}$

3. Perbandingan dengan sistem berbasis bunga

Karena dasar-dasar pembangunan dalam ekonomi Islam dilaksanakan melalui peyemarakan aktivitas wirausaha, maka pasokan modal untuk para wirausahawan prospektif berbasis bagi hasil/rugi merupakan bagian dari proses dalam mekanisme untuk menghasilkan para wirausahawan dalam perekonomian. ${ }^{16}$ Sedangkan dalam ekonomi berbasis bunga, proses pembangunan pada dasarnya dilakukan melalui akumulasi modal. Namun akumulasi modal ini tidak dirancang untuk menghasilkan lebih banyak wirausahawan. Mereka yang sudah memiliki modal diasumsikan lebih mampu dalam akumulasi modal. Ada mekanisme yang terbangun dalam sistem yang dapat menjamin pembangkitan akumulasi modal dalam sistem ekonomi berbasis bunga. ${ }^{17}$

Fahim Khan mengasumsikan strategi pembangunan dalam kerangka kelembagaan kapitalis di negara sedang berkembang yang padat penduduk. Stok tenaga kerja yang berlebihan akan memasuki angkatan kerja ketika dapat terserap ke dalam sektor berupah dengan tingkat upah yang mulai naik. Sumber daya manusia ini umumnya tidak memiliki faktor-faktor produksi lain kecuali modal manusia, yakni diri mereka sendiri. Tidak ada kerangka lembaga yang dapat menyediakan bagi mereka sumber daya komplementer (sumber daya finansial/fisik) untuk memulai usaha sendiri. Kurang tersedia peluang kewirausahawanan yang cukup untuk mengawali usaha sendiri semisal mengumpulkan kayu dari hutan dan menjualnya di pasar. ${ }^{18}$

Tidak akan ada suplai modal finansial untuk kewirausahaan kecuali jika ada jaminan kepastian bahwa laba atas investasi lebih tinggi dari bunga. Seseorang yang membutuhkan modal finansial untuk memulai sebuah proyek akan harus membayar bunga tetap terlepas dari kondisi usahanya untung atau kerugian. Taruhannya terlalu banyak, seperti kehilangan semua usaha manusia yang diinvestasikan dalam proyek, keharusan menutup hilangnya modal untuk mengembalikan pinjaman secara penuh, serta keharusan membayar bunga.

Sistem perbankan menawarkan modal finansial untuk mereka yang sudah memiliki modal. Lebih banyak modal yang dimiliki seseorang, semakin banyak pinjaman modal yang dapat diperolehnya dari bank. Sistem perbankan justru kontra-produktif terhadap upaya mendukung kelebihan pasokan sumber daya manusia untuk mencari kegiatan usaha mandiri produktif. Mereka yang memiliki sumber daya keuangan lebih memilih untuk menabungnya di bank untuk mendapatkan sewa uang yang tetap daripada menggunakan sumber daya finansial tersebut dalam kegiatan kewirausahaan mereka sendiri atau untuk dilibatkan dalam aktivitas kewirausahaan orang lain, kecuali jika mereka yakin akan keuntungan yang lebih tinggi dari suku bunga. ${ }^{19}$

\footnotetext{
${ }^{15}$ Ibid., 234.

${ }^{16}$ Ibid., 235.

${ }^{17}$ Ibid., 236.

18 Ibid.

${ }^{19}$ Ibid., 237.
} 
4. Pelajaran bagi strategi pembangunan

Fahim Khan berkali-kali menegaskan kejelasan strategi pembangunan ekonomi dalam perspektif Islam yang menekankan lebih pentingnya pengaturan institusional untuk secara langsung melibatkan orang dalam kegiatan kewirausahaan mereka sendiri daripada strategi memanjakan kapitalis untuk menciptakan kesempatan kerja dengan upah pasti di pasar kerja. Ekonomi Islam memiliki mekanisme built-in untuk mendukung strategi tersebut. ${ }^{20}$

\section{Pemikiran Umer Chapra Tentang Pembangunan Ekonomi Islami}

Umer Chapra sepakat dengan nilai dasar dan tujuan ekonomi pembangunan yang telah dibahas oleh ilmuwan dan ulama sebelumnya. Menurut penulis pemikiran Chapra lebih condong pada upaya penyegaran pemikiran, respon, dan tawaran solusi atas masalah-masalah ekonomi pada umumnya dan pembangunan khususnya yang sedang dihadapi umat Islam. Pemikiran Umer Chapra tentang pembangunan ekonomi perspektif Islam di antaranya sebagai berikut:

1. Inkonsistensi Pembangunan Ekonomi

Ekonomi pembangunan tidak memiliki identitas tersendiri. Ia merupakan cabang dari tiga aliran utama ekonomi, yaitu Neo-Klasik, Keynesian, dan Sosialis. Ketiga aliran ini memiliki akar dari pandangan dunia Barat. Strategi-strategi yang diajukan dalam ekonomi pembangunan juga didasarkan pada pandangan dunia Barat. Strategi khusus yang diikuti pada satu periode waktu tertentu, bagaimanapun juga bergantung pada arus utama ekonomi yang sedang naik daun pada saat itu. Dengan demikian, ekonomi pembangunan telah menyaksikan perubahan maju dan mundur dari strategi Keynesian dan Sosialis sampai pada strategi Neo-Klasik. ${ }^{21}$

Kegonjang-ganjingan ekonomi pembangunan dari pasar ke negara dan kembali lagi ke pasar telah menjauhkannya dari fokus perhatian yang kuat. Ia telah mengantarkan kepada analisis-analisis dan resep-resep kebijaksanaan yang saling bertentangan dan telah melahirkan inkonsistensi serta ketidakpastian dalam program-program pembangunan negara-negara yang sedang berkembang, yang pada gilirannya menimbulkan bahaya besar bagi kesehatan dan pembangunan ekonomi mereka. Pekerjaan yang harus dihadapi oleh negara-negara ini sangatlah sulit. Mereka tidak saja harus membangun perekonomiannya dalam suatu cara yang dapat mengantarkannya kepada efisiensi dan pemerataan dalam penggunaan sumber daya-sumber daya yang sangat terbatas, tetapi juga harus menghapuskan ketidakseimbangan yang diakibatkan oleh implementasi dari resep yang salah. ${ }^{22}$

Oleh karena itu, ekonomi Neo-Klasik, Keynesian, dan Sosialis merupakan produk dari pandangan dunia pencerahan, sehingga dalam pendekatannya terhadap analisis masalah yang dihadapi manusia dan realisasi kesejahteraan umat dapat dikatakan kaum sekuler. Karena mereka terlalu menekankan konsumsi dan kepemilikan materi sebagai

\footnotetext{
20 Ibid., 238.

${ }^{21}$ M. Umer Chapra, Islam dan Tantangan Ekonomi, Terj. Ikhwan Abidin Basri (Jakarta: Gema Insani Press, 2000), 147.

${ }^{22}$ Ibid., 28-29.
} 
sumber kebahagiaan manusia, dan secara implisit tidak berkomitmen terhadap persaudaraan sesama manusia serta keadilan sosio-ekonomi. Di samping itu, kaum sekuler juga tidak memperhatikan peran nilai-nilai moral dalam alokasi dan distribusi sumberdaya. $^{23}$

Karena sempitnya pemikiran mereka, Umer Chapra menyebutkan tidak adanya motivasi untuk mengedepankan kepentingan sosial dalam kerangka yang mereka susun. Melainkan apabila hal tersebut secara otomatis memberikan manfaat baginya sebagai balasan yang tidak langsung dari pemenuhan kepentingan diri sendiri. ${ }^{24}$

2. Strategi pembangunan ekonomi islami

a. Penyaringan yang merata atas klaim yang berlebihan

Kelangkaan sumber-sumber daya relatif dibandingkan klaim yang tidak terbatas meniscayakan adanya suatu perangkat penyaringan. Semua klaim pada sumber daya harus melewati filter ini untuk menyamakannya dengan ketersediaan sumber-sumber daya dan untuk merealisasikan sasaran-sasaran sosio-ekonomi. ${ }^{25}$

Kapitalisme membiarkan konsumen mengkonsumsi apa saja yang mereka inginkan menurut preferensi individualnya untuk mendapatkan kegunaan yang maksimal. Juga membiarkan para produsen memproduksi apa saja yang mereka inginkan dalam merespon preferensi konsumen dengan menggunakan kombinasi faktor-faktor produksi apa saja yang dirasa meminimalkan ongkos dan memaksimalkan keuntungan. ${ }^{26}$

Islam mempunyai kelebihan dengan memperkenalkan filter moral. Pada alokasi sumber daya akan dipasang dua lapis filter. Pertama, menyerang persoalan keinginan yang tidak terbatas pada pusat muaranya, kesadaran individu yang paling dalam, dengan mengubah skala preferensinya seiring dengan tuntutan kedudukannya sebagai khalifah dan prinsip 'adālah atau keadilan. Kedua, yaitu harga yang ditentukan oleh pasar. ${ }^{27}$

Filter moral menjadikan klaim-klaim pada sumber daya sebagai suatu fungsi kesejahteraan manusia dan tidak membiarkan penggunaannya untuk tujuan lain. Ia tidak akan mengizinkan, umpamanya penggunaan sumber-sumber daya bagi aktivitas-aktivitas yang secara moral dilarang, aktivitas-aktivitas yang akan membunuh atau membahayakan manusia, binatang, atau tumbuh-tumbuhan baik sekarang maupun di masa yang akan datang, karena akan mereduksi kesejahteraan mereka. Ia menuntut gaya hidup sederhana dan tidak membiarkan sikap berlebihan atau penggunaan sumber-sumber daya untuk tujuan-tujuan pamer diri atau kompetisi semata, penggunaan-penggunaan yang tidak membuat perbedaan riil dalam kesejahteraan. Ia tidak membolehkan perusakan atau penggunaan sumber-sumber daya yang mubazir, seperti membakar makanan untuk menaikkan harga. ${ }^{28}$

\footnotetext{
${ }^{23}$ Ibid, 29.

24 Ibid.

${ }^{25}$ Ibid., 216.

${ }^{26}$ Ibid.

${ }^{27}$ Ibid., 218.

${ }^{28}$ Ibid.
} 
b. Motivasi yang benar

Sekiranya dimensi keimanan kepada pembalasan di depan Tuhan Yang Maha Kuasa, yang mengetahui segala sesuatu dan kehidupan setelah kematian diinjeksikan, maka suatu rasionalitas yang lebih tinggi telah diciptakan. Kepercayaan ini akan memasok kekuatan motivasi bagi perilaku yang berorientasi sosial dengan memberikan kepentingan diri sendiri suatu perspektif tak terbatas. Hal ini mengandung implikasi bahwa kepentingan diri individu sendiri tidak saja akan dipenuhi dengan perbaikan kondisi kehidupannya di dunia, tetapi juga di akhirat.

Oleh karena itu, jika ia memang benar-benar rasional dan mencari apa yang menjadi kepentingan terbaiknya, ia tidak akan bertindak hanya untuk memenuhi jangka pendek keduniawiannya saja, melainkan mencoba menjamin jangka panjangnya dengan bekerja untuk kemaslahatan orang lain lewat reduksi dalam konsumsinya yang tidak penting dan mubazir, meskipun secara finansial ia mampu melakukannya.

c. Restrukturisasi sosio-ekonomi dan finansial

Mekanisme filter dan sistem motivasi tidak akan berdaya sekiranya tidak dilengkapi dengan sebuah lingkungan sosio-ekonomi dan politik yang kondusif untuk merealisasikan tujuan. Lingkungan sosial harus kondusif bagi pelaksanaan aturan keamanatan dengan tidak membolehkan kepemilikan materil dan konsumsi pamer menjadi sumber prestise. Lingkungan finansial dan ekonomi juga harus disusun sedemikian rupa sehingga manusia ekonomi tidak dilahirkan, dan sekalipun dilahirkan, tidak akan hidup lama. ${ }^{29}$

Jika sistem nilai masyarakat menghancurkan sumber prestise manusia ekonomi, dan jika ini diperkuat lebih lanjut dengan restrukturisasi ekonomi dan finansial sedemikian rupa sehingga mesin alokatif dan distribusi perekonomian tidak mendukung penggunaan sumber-sumber daya untuk tujuan-tujuan menggagalkan realisasi maqāsid al-shari' 'ah, maka kualitas lebih unggul dan berarti akan dapat diperkenalkan pada pola perilaku konsumsi, mencari penghidupan, dan investasi individual.

d. Peran negara

Sekalipun Islam mengakui kebebasan individu dan peran mekanisme harga dalam mendorong efisiensi, ia tidak menganggap kekuatan pasar sebagai sesuatu yang sakral. Operasi kekuatan-kekuatan pasar yang buta tidak secara otomatis akan memberikan imbalan pada usaha-usaha yang secara sosial produktif, menghapuskan eksploitasi, atau membantu yang lemah dan yang membutuhkan. Karena itu, perlu tanggung jawab negara untuk menjamin realisasi maqāsid al-sharí 'ah ini. ${ }^{30}$ Ia tidak perlu menggunakan kekuatan untuk mencapai tujuan ini, atau bergantung pada pemilikan dan pengoperasian sebagian besar perekonomian. Yang dituntut adalah penggunaan kebijakan dalam memberlakukan syariah.

\footnotetext{
${ }^{29}$ Ibid., 225.
}

${ }^{30}$ Ibid., 227. 
e. Elemen kebijakan pembangunan ekonomi

Pendekatan Islam yang berdimensi empat, meliputi melengkapi mekanisme pasar dengan filter moral, memotivasi individu ikut menanggung kepentingan sosial, restrukturisasi sosioekonomi, dan peranan positif pemerintah. Setidaknya harus dapat membuktikan lebih efektif dalam menjamin kesejahteraan semua anggota masyarakat dari pada pendekatan kapitalis atau sosialis yang berdimensi tunggal dan hanya mengandalkan pada kepentingan diri sendiri dan kekuatan pasar, atau hanya mengandalkan kolektifitas dan perencanaan pusat. ${ }^{31}$

Menurut Umer Chapra, dalam mengambil kebijakan pembangunan ekonomi, setidaknya harus memenuhi dua kriteria, yaitu (1) tindakan kebijakan itu harus mampu melakukan kontribusi terhadap realisasi maqāsid al-sharí 'ah, tanpa harus berbenturan dengan ajaran Islam serta tindakan tersebut tidak mengarah pada peningkatan klaim terhadap sumber-sumber daya; (2) tidak boleh dipenuhi lewat kerangka kerja optimalitas pareto. ${ }^{32}$

Suatu strategi yang memandang bahwa meningkatkan sumber daya untuk tujuan yang lain hanya akan mengarah pada kegagalan dan ketidakseimbangan. Kebijakan harus di uji coba melalui filter nilai-nilai Islam. Di bawah ini ada lima tindakan kebijakan yang diajukan bagi pembangunan yang disertai dengan keadilan dan stabilitas. Lima kebijakan tersebut adalah: ${ }^{33}$

1) Memberikan kenyamanan kepada faktor manusia.

2) Mereduksi konsentrasi kekayaan.

3) Melakukan restrukturisasi ekonomi.

4) Melakukan restrukturisasi keuangan.

5) Rencana kebijakan strategis.

\section{Perbandingan Pemikiran Fahim Khan dan Umer Chapra Tentang Pembangunan Ekonomi Islami}

Fahim Khan memakai istilah surplus tenaga kerja pada permasalahan yang sedang dihadapi negara berkembang, sedangkan Umer Chapra menggunakan istilah pengangguran pada salah satu problem yang dihadapi negara berkembang. Hanya saja strategi tersebut tidak dikhususkan untuk negara yang mengalami kelebihan tenaga kerja, tetapi bersifat global. Fahim Khan berasumsi bahwa, dengan menyemarakkan usaha produktif secara mandiri akan lebih cepat menyerap tenaga kerja, selain itu sumber daya manusianya secara otomatis akan turut mengalami perubahan, karena mereka ikut serta terlibat dalam kegiatan kewirausahaan.

Sementara letak corak perspektif Islamnya dalam gagasan Fahim Khan adalah adanya dukungan kerangka kelembagaan, yaitu dengan bantuan kemitraan, seperti muḍārabah dan shirkah berbasis profit and loss sharing, berbeda dengan sistem bunga yang diberlakukan oleh strategi konvensional.

Sedangkan Umer Chapra memiliki corak pemikiran mengenai strategi pembangunan ekonomi lebih bersifat umum atau global yang tidak dikhususkan pada kondisi tertentu.

\footnotetext{
${ }^{31}$ M. Umer Chapra, Islam dan Pembangunan, 84.

${ }^{32}$ Ibid., 85.

${ }^{33}$ Ibid., 5 .
} 
Artinya, strategi tersebut berlaku dalam segala fenomena negara apapun. Karena pemikiran beliau pada dasarnya memang berangkat dari keprihatinannya terhadap sistem ekonomi liberalis dan sosialis.

Dalam pembangunan ekonomi Umer Chapra mencurahkan gagasannya pada empat elemen pokok, yaitu filter moral, motivasi yang benar, restrukturisasi sosio-ekonomi, dan peran negara. Apabila keempat elemen tersebut bisa berjalan secara bersama-sama maka akan terciptalah pembangunan yang seimbang, adil dan merata. Yang menjadi ciri khas islaminya, adalah pembangunan dengan memperhatikan elemen tersebut diharapkan akan mampu tercapainya konsep maqāșid al-sharì'ah, yaitu terpeliharanya jiwa, akal, keturunan, agama, dan harta, sehingga berbeda dengan konsep konvensional yang sama sekali tidak mementingkan unsur filter moral atau keadilan terhadap sesama, bahkan mereka hidup dengan rasa sekuler dan hedonisme. Yang menyebabkan apa saja dapat mereka lakukan, termasuk eksploitasi sumber daya dan adanya ketidakadilan di antara salah satu pihak.

\section{Faktor-Faktor yang Mempengaruhi Adanya Persamaan dan Perbedaan Pemikiran Fahim Khan dan Umer Chapra Tentang Pembangunan Ekonomi Islami}

Berdasarkan data perbandingan di atas, penulis dapat menganalisis faktor-faktor yang mempengaruhi adanya persamaan dan perbedaan pemikiran Fahim Khan dan Umer Chapra tentang pembangunan ekonomi, dengan menggunkan teknik analisis wacana kritis. Karakteristik penting dari teknik analisis wacana kritis terdiri dari lima unsur yang meliputi:

1. Tindakan

Dalam hal ini, pemikiran Fahim Khan dan Umer Chapra tentang pembangunan ekonomi berangkat dari keprihatinannya terhadap strategi yang diterapkan oleh konvensional dalam mengatasi problematika di negara-negara sedang berkembang yang berupaya memacu pembangunan ekonomi.

Dalam pndangan mereka strategi konvensional dianggap mengalami kegagalan dalam mencapai fase tinggal landas dan dirasa kurang tepat karena secara jangka lama dapat menyebabkan eksploitasi sumber daya alam serta terjadinya ketidak adilan.

Sehingga kedua tokoh ekonom muslim tersebut mencurahkan gagasannya disertai tindakan yang dituangkan dalam karya-karya monumentalnya. Sebagai bentuk sanggahan atau aksi atas ketidak setujuannya terhadap strategi yang di terapkan oleh kaum konvensional.

2. Konteks

Umer Chapra hidup pada kondisi sosial dan politik yang sama dengan Fahim Khan, karena kelahiran dan masa muda beliau sebelum menimba ilmu ke Negeri Paman Sam, ia habiskan di negara kelahirannya, yaitu Pakistan. Dalam konteks ini, faktor tersebut menjadikan salah satu penyebab adanya kesamaan pemikiran, sehubungan dengan kajian mengenai pembangunan ekonomi. Mereka berdua sama-sama berasumsi bahwa masalah yang dihadapi negara berkembang adalah banyaknya angka pengangguran, sebagaimana mereka melihat fenomena di Negara Pakistan pada saat itu.

3. Historis

Sebagaimana diketahui bahwa latar belakang pendidikan Fahim Khan dan Umer Chapra sama-sama merupakan ekonom lulusan Amerika Serikat (Barat), walaupun pada 
mulanya mereka mengenyam pendidikan di Pakistan terlebih dahulu sebelum melanjutkan di Amerika Serikat. Artinya, mereka mempelajari ekonomi Islam dengan menggunakan pendekatan rasional (Barat) yang tentunya dengan memperhatikan petunjuk dari naș-naș Islam.

Dalam hal ini, faktor latar belakang pendidikan mereka yang notabene merupakan lulusan Amerika Serikat (Barat) menjadi faktor penyebab terjadinya kesamaan pandangan serta konsep pemikiran. Fahim Khan dan Umer Chapra sama-sama menganggap bahwa salah satu dari masalah yang sedang dihadapi negara berkembang adalah tingginya angka pengangguran/surplus tenaga kerja sebagaimana yang telah dikemukakan oleh pakar ekonomi Barat.

Di samping itu, latar belakang pendidikan ini juga menjadikan Fahim dan Chapra memiliki spesialisasi dalam ilmu ekonomi yang berbeda. Fahim Khan yang memiliki spesialisasi dalam ekonomi statistik menjadikan pemikirannya terhadap ekonomi Islam merupakan hasil pengamatan atas kecendrungan perilaku masyarakat yang terjadi di lapangan.

Sementara, Umer Chapra dengan spesialisasi ekonomi internasional. Sehingga ia membentuk pemikirannya terhadap ekonomi Islam, memisahkan kajian figh almu'āmalah dengan kajian ekonomi Islam dengan berlandaskan pada nilai-nilai yang universal akan tetapi tetap menjadikan nas-nas sebagai patokan.

4. Kekuasaan

Faktor sosial politik memang memiliki pengaruh yang cukup besar dalam corak pemikiran seseorang. Faktor ini juga mempengaruhi pemikiran dari Fahim Khan dan Umer Chapra dalam mangkaji ekonomi Islam, khususnya pada aspek pembangunan ekonomi.

Fahim Khan merupakan seorang tokoh yang dilahirkan di India pada tahun 1946. Beliau melaksanakan studi di Universitas Punjab (Pakistan) di bidang statistik. Dengan kehidupan politik dan sosial pada kedua negara yang saling bertetangga (India-Pakistan) yang bisa dibilang belum stabil karena baru merdeka dan akibat perang saudara, sehingga beliau memutuskan untuk pindah ke Amerika Serikat sekaligus melanjutkan studinya di Universitas Boston.

Dengan kehidupan beliau di dua kondisi politik dan sosial yang berbeda, menjadikannya sadar akan pembangunan ekonomi yang dicetuskan oleh pakar ekonom dari Barat belum mampu menciptakan pembangunan yang menjadikan sumber daya manusia sebagai prioritas utama, dan padahal fenomena di Pakistan sedang dilanda masalah surplus tenaga kerja. Umer Chapra hidup pada kondisi sosial dan politik yang sama dengan Fahim Khan, karena kelahiran dan masa muda beliau sebelum menimba ilmu ke Negeri Paman Sam, ia habiskan di negara kelahirannya, yaitu Pakistan.

Dalam konteks ini, faktor tersebut menjadikan salah satu penyebab adanya kesamaan pemikiran, sehubungan dengan kajian mengenai pembangunan ekonomi. Mereka berdua sama-sama berasumsi bahwa masalah yang dihadapi negara berkembang adalah banyaknya angka pengangguran, sebagaimana mereka melihat fenomena di Negara Pakistan pada saat itu. 


\section{Ideologi}

Mazhab Mainstream merupakan salah satu aliran-aliran pemikiran ekonomi Islam kontemporer yang memiliki anggapan bahwa perbedaan utama antara ilmu ekonomi konvensional dengan ekonomi Islam adalah dalam hal cara mencapai tujuan. Tokohtokohnya banyak dipelopori dari IDB (Islamic Development Bank).

Dalam karakteristik ini, dilihat dari segi karirnya Fahim Khan dan Umer Chapra merupakan tokoh yang sama-sama beraliran Mazhab Mainstream, sehingga pemikiran yang dihasilkan dapat saling mempengaruhi.

\section{Kesimpulan}

Fahim Khan mengkhususkan strategi pembangunan ekonomi terhadap negara yang surplus tenaga kerja dengan membuka dan menyemarakkan kewirausahaan disertai dengan dukungan kelembagaan berbasis kemitraan dengan sistem profit and loss sharing. Sementara pemikiran Chapra tidak ada pengkhususan terhadap strategi yang ia tawarkan, tak lain adalah merupakan salah satu hasil kritik terhadap eksistensi kapitalis dan sosialis yang dipandang telah gagal dalam mengatasi masalah yang sedang dihadapi negara berkembang. Strateginya menitikberatkan pada empat elemen penting, yaitu filter moral, motivasi yang benar, restrukturisasi sosio-ekonomi, dan peran negara.

Terdapat lima krakteristik yang mempengaruhi terhadap faktor-faktor yang menyebabkan adanya perbedaan dan persamaan pemikiran Fahim Khan dan Umer Chapra tentang pembangunan ekonomi, yaitu tindakan, konteks, historis, kekuasaan dan ideologi.

\section{Daftar Rujukan}

Chapra, M. Umer. Islam dan Pembangunan Ekonomi, Terj. Ikhwan Abidin Basri. Jakarta: Gema Insani Press, 2000. . Islam dan Tantangan Ekonomi, Terj. Ikhwan Abidin Basri. Jakarta: Gema Insani Press, 2000.

Chaudry, M. Sharif. Prinsip Dasar Sistem Ekonomi Islam, Terj. Suherman Rosyidi. Jakarta: Kencana, 2012.

Ismail, M. Rizal. "Pembangunan Ekonomi Menurut Islam", dalam http://mrizalismail.blogspot.co.id/2012/01/pembangunan-ekonomi-menurut-islam.html.

Khan, Fahim. Esai-Esai Ekonomi Islam, Terj. Suherman Rosyidi. Jakarta: Rajawali Press, 2014.

Markfield Institute Of Hinger Education, "Dr M Fahim Khan", dalam https://www.mihe.ac.uk/honorary-visiting-fellows/dr-m-fahim-khan.

Murtadho, Ali. "Formulasi Konsep Islam Tentang Pembangunan Ekonomi Padat Penduduk: Analisis Pemikiran Fahim Khan" dalam Laporan Penelitian Individual LP2M UIN Walisongo Semarang, 2014. . "Strategi Pembangunan Ekonomi yang Islami Menurut Fahim Khan" dalam Jurnal Economica. Vol. 7, Edisi. 2, Oktober 2016.

Wikipedia.org, "M. Umer Chapra”, dalam https://id.m.wikipedia.org/wiki/M._Um er_Chapra. 